\title{
水群下面の凹凸を考慮したアイスブームへの伝 達荷重に関する基礎的研究 ICE LOAD ON ICE BOOM CONSIDERING ROUGHNESS OF SEA ICE BOTTOM
}

\author{
木岡信治 1 ・竹内貴弘 2 \\ Shinji KIOKA and Takahiro TAKEUCHI
}

\author{
1正会員 博（工）（独）寒地土木研究所（干062-8602 札幌市豊平区平岸1条3丁目1番34号） \\ 2正会員 工博 八戸工業大学大学院教授 環境建設工学科（干031-8501 八戸市妙大開88-1）
}

\begin{abstract}
We made the experiments on interaction between sea ice floes and ice booms, which were especially focused on the effect of the roughness under ice floe on the ice loads acting on the ice booms. While the ice load on ice boom in case of the ice floes with undulation was proportional to the square of current velocity as well as in case of the flat ice floes, the ice load by the ice floes with undulation nonlinearly increased with ice cover length unlike the case of the flat ice floes. We estimated the drag coefficient of the each ice condition in this experiments from the theoretical model [Kioka et al.,2009] and related the coefficients with statistical values of the ice conditions. We also roughly estimated the drag coefficient of actual sea ice with undulation (deformed ice) in the Okhotsk Sea by using these results, and got the drag coefficient of $C s=0.03-0.04$.
\end{abstract}

Key Words : Sea ice, drag force, ice boom, roughness

\section{1.はじめに}

サロマ湖では，過去に多発していた湖内への流水 流入によるホタテなどの養殖施設の被害を防止する ために湖口部に防水施設（アイスブーム）が設置さ れ，さらに，2009 年には，能取湖口での設置も完 了した. 今後も多目的でアイスブームが活用される 可能性もあり，より合理的な設計方法が望まれる. また, 一般の沿岸施設の流水群との接触による劣化 損傷評価の観点からも，流水群挙動や接触荷重・圧 力などを推定する手法の確立が必要である。過去に

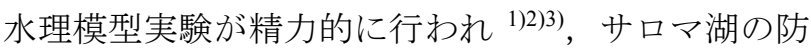
水施設の設計に大きく貢献した。しかし，非連続体 である流水群との構造物との干渉が非常に複雑であ り, 特に, 湖口部の形状 - 地形, 水群下面凹凸等に 大きく依存し，未だ多くの課題が残されている．著 者等は，過去の実験を拡張した水理模型実験 ${ }^{4) 5)}$, 理論解析 ${ }^{6)}$, DEM による数值計算 ${ }^{5) 7}$ といった多角 的なアプローチより, 流水群挙動や伝達荷重等（施 設に作用する氷荷重）の推定手法の構築を目的とし た研究を行っている. このうち, 既報の水理模型実 験 4)5)では，特に水の下面が平坦な流水群の場合に ついて実施してきた。しかし，現実の水野では変形 海水と言われる水盤相互の潜り込み等によって下面 は凹凸例えば 8) である場合が多い。過去に上田ら ${ }^{3)}$ は， 一枚の板状のパラフィン盤の下面に規則的な凹凸を 設けてこれを台車でけん引することにより，抗力係 数などの推定を試みている. 本研究では, より実現
象に近い状態で行うため, 回流水路に, 厚さの異な る多数の円柱型の模擬水群を流し，アイスブームへ トラップさせた。一般に氷に作用する抗力は圧力 (形状) 抗力と摩擦(せん断)抗力からなるが ${ }^{3)}$, 本 研究では，特に凹凸の摩擦抗力成分に着目した様々 な凹凸状態の水群の伝達荷重や抗力係数などについ て調べた。また，才ホーツク海における流水群下面 凹凸の観測結果から抗力係数を概略的に推定する方 法についても若干検討を加えた。

\section{2. 実験方法}

実験方法は既報 ${ }^{4)}$ 5) とほぼ同様であるため要点の み述べる。幅 $2 \mathrm{~m} \times$ 長さ $10 \mathrm{~m}$ の木製水路（水深約 $11 \mathrm{~cm})$, 水位差 (上流側で水を連続供給)を利用し て流れを発生し, 密度と摩擦係数が実海水と概水等 しいパラフィン製の模擬水盤 ${ }^{2)}$ を流下させてアイ スブームでトラップさせた（写真-1）。模型アイス ブームは, 既報と同様に, 水路中央に 1 スパン, そ の両側に半スパンのブームを設置し，その長さは， 支柱間隔の 1.2 倍とした。模型縮尺は $1 / 100$ 程度を 想定し，アイスブームを係留する支柱間隔を $b=100 \mathrm{~cm}$ （純径間 $B=92 \mathrm{~cm}$ ），表面流速を $0.05 〜$ $0.15 \mathrm{~m} / \mathrm{s}$ (目標值)の範囲で実施した。また, 水群の凹 凸を, 直径 $a=3 \mathrm{~cm}$ の円柱で, 厚さの異なる 2 種類 の模擬水盤 $[5 \mathrm{~mm}$ および $20 \mathrm{~mm}]$ により表現した（写 真-2）.この場合，その凹凸差である振幅 $\Delta h$ を一 
定に保ち，その配合率を変えて様々な凹凸状態を創 出した. $\Delta h$ は模型水の比重 $(0.9)$ を考慮して, $0.9 \times$ $(0.02-0.005)=0.0135 \mathrm{~m}$ となる. なお, これらの水 群はランダムに流下させた．表-1 には，その配合 率として $20 \mathrm{~mm}$ 厚の水盤（以下 $20 \mathrm{~mm}$ 水という） の混入率 $(\xi)$ と平均的な波数を示した（直線上に 均等に配列した場合で，前述のように実際には，2 種類の混合はランダムに行う）。

次に計測項目も既報と同様，アイスブームの張力 と支柱に作用寸る荷重, 水路内流速, および水位で, 測定方法も同様である。また水路内流速は, 既報 ${ }^{4) 5}$ )の方法により間接的に断面平均流速を推定し, データの整理には，流速の代表值としてこれを用い た. また流速の鉛直分布は, 水群（凹凸）および水 路床 (滑らか) からの境界層の発達により, やや水 路床よりに最大をもつ分布であった。

本研究では, 凹凸の状態が氷群伝達荷重へ与える 影響を調べるともに, 水群抗力の解析解 ${ }^{4)} よ り$, 各凹凸状態に応じた抗力係数を推定する一方, 凹凸 の幾何学的形状から， 凹凸特性を表す，パワースペ クトル, 混入率や波数, 平均パワー (分散) などの 関係を理論的に導出, 整理した。 また, それらの量 と抗力係数とを関連づけた。 さらに，それらの関係 を利用し，オホーツク海での流水群下面凹凸の観測 結果から, その抗力係数の概略的な推定を試みた.

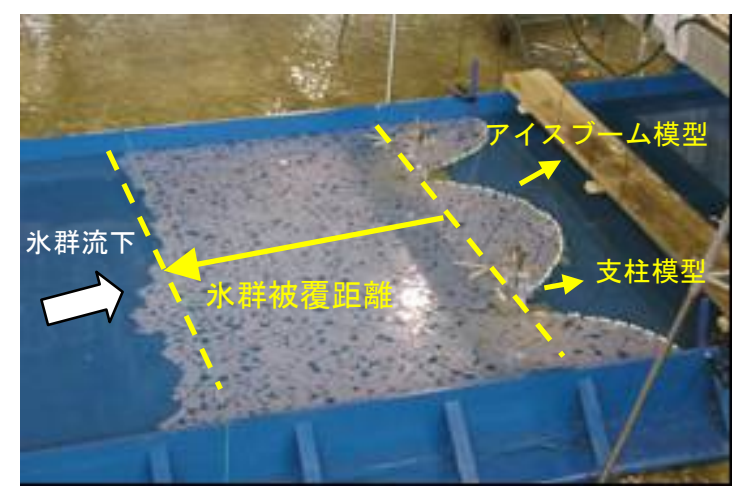

写真-1 アイスブームの実験施設

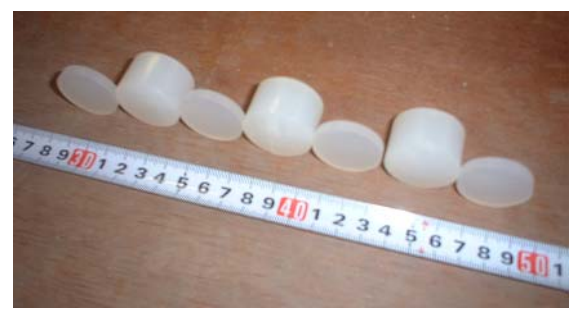

写真-2 実験に用いた氷群模型

表-1 凹凸水群の実験条件

\begin{tabular}{|c|c|c|}
\hline & $\begin{array}{c}20 \mathrm{~mm} \text { 厚模擬水 } \\
\text { 盤の混入率 } \xi(\%)\end{array}$ & $\begin{array}{l}\text { 波数 } k p \\
\text { (cycle/m) }\end{array}$ \\
\hline ケース1 & 25 & 8.33 \\
\hline ケース 2 & 11.1 & 3.7 \\
\hline ケース 3 & 4 & 1.33 \\
\hline ケース4 & 1.56 & 0.52 \\
\hline
\end{tabular}

\section{3. 実験結果および考察}

\section{（1）アイスブームへの伝達荷重の速度依存性}

図-1 には例として, $20 \mathrm{~mm}$ 水の混入率 $\xi$ が $4 \%$ および $25 \%$ の水群が中央部アイスブームに及ぼす 伝達荷重と断面平均流速 $\left(V_{0}\right)$ との関係を示寸. 荷重 の代表值として氷群被覆長 $(L)$ が $2 \mathrm{~m}$ と $4 \mathrm{~m}$ 地点に おける荷重を図示しているが，氷の下面が平坦な場 合と同様に，概ね速度の 2 乗に比例していると考 えられる。 これで, 凹凸水群においても, 速度の 2 乗で除して規格化 ${ }^{5)}$ できる根拠が得られた.

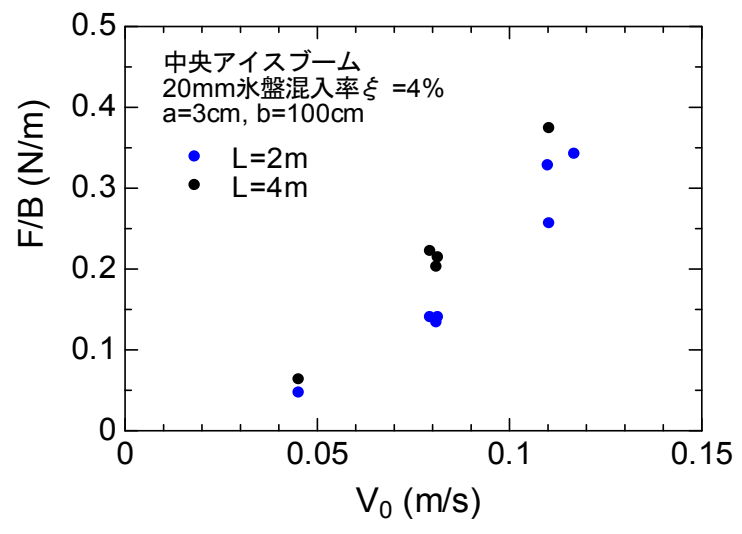

(a) $20 \mathrm{~mm}$ 水混入率 $\xi=4 \%$

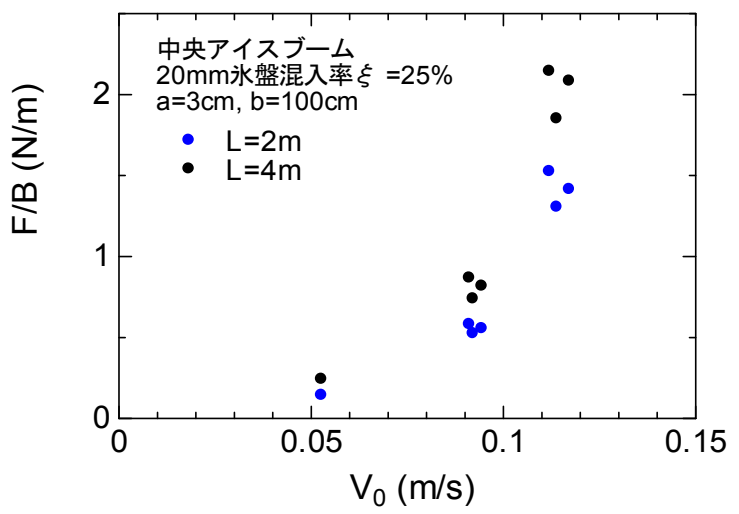

(b) $20 \mathrm{~mm}$ 水混入率 $\xi=25 \%$

図-1 流れの速度とアイスブームに作用寸る荷重の関 係例（中央アイスブーム）

\section{（2）伝達荷重と永群被覆長との関係の検討および， 各凹凸水群の抗力係数の推定}

図-2(a) には, 各凹凸水群における水群被覆長 $(L)$ とアイスブーム（中央部）に作用する荷重（ア ンサンブル平均）を示した。なお, 荷重はアイス ブームの幅 $B$, 流体密度 $\rho$, 断面平均流速 $V_{0}$ の 2 乗 で除して規格化している。 この図から $\xi=0$, 寸なわ ち平坦な水では今までの議論からこの範囲では直線 と見なされるが，凹凸を有するにつれて，曲線的に なってくる感がある.ここで, 次式に示す流下方向 の伝達荷重の理論モデル ${ }^{4)}$ を適用してみる. 


$$
\begin{aligned}
\frac{F}{\rho V_{0}^{2} B}=\frac{C s B}{4 K_{0} \tan \phi}\left[1-\exp \left\{-2 K_{0} \tan \phi \frac{L}{B}\right\}\right] \\
+\frac{1}{2} C_{d} h^{\prime} \exp \left\{-\frac{2 K_{0} \tan \phi}{B} L\right\}
\end{aligned}
$$

ここに，F は流下方向の伝達荷重（アイスブームに 及ぼす荷重),$B$ は水路幅(ここではアイスブーム の幅に相当), $\rho$ は水の密度, $\varphi$ は水群の内部摩擦角, $K_{0}$ は静止粉体圧係数に準じるもの，Cs， $C_{d}$ はそれ ぞれ, 摩擦 (せん断) 抗力係数, 圧力抗力係数, $h$, は水の喫水深，である。

上式は，主働粉体圧の Janssen 式に準じるものと 考えることができる. 水が平坦で，単純な境界条件 を有する構造物などの理想的な場合には， $L=0$ の とき圧力抗力となるが，本実験では，支柱位置を $L=0$ とし, これより上流側に氷群被覆長としてい る。しかし実際には，支柱〜ブームまでも摩擦抗力 が働いており，これを分離するのは困難であるため, $L=0$ のとき $F=0$ となるよう補正する. この場合に は水の喫水深 $h$ 'に依存する圧力抗力を無視するこ とになるが，式(1)あるいは，あるいは図-2(a)から も推察されるように, 被覆長が大さくなるほど, 摩 擦抗力が支配的となるため, 本研究では摩擦抗力 Cs について検討することとした.ここで，式(1)の 右辺第二項を無視し, さらに $B$ で除して無次元化

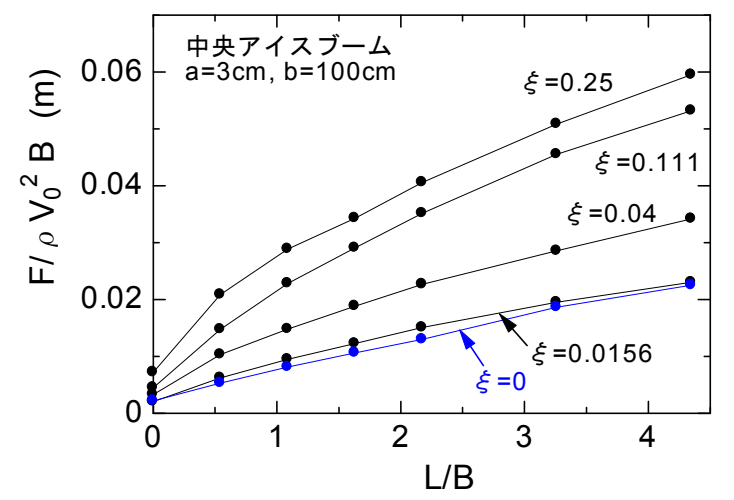

図-2（a）水群被覆長 $(L)$ とアイスブーム（中央部） に作用する伝達荷重 $(F)$ （アンサンブル平 均）との関係例

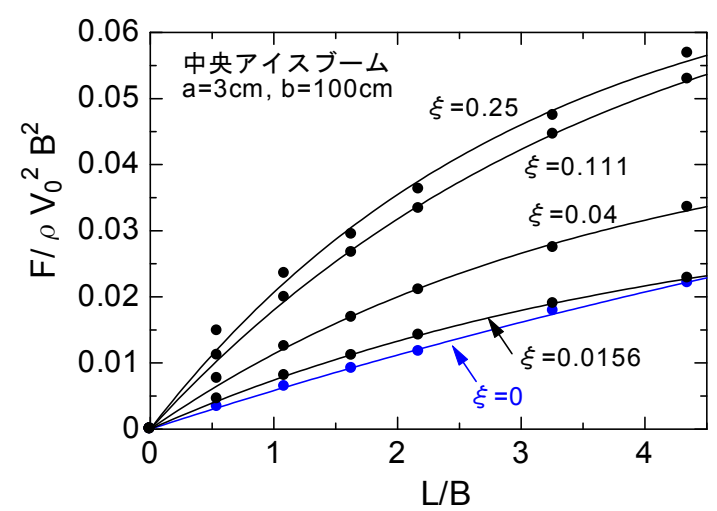

図-2(b) 上図の補正 $(L=0$ のとき $F=0) \quad$ （圧力抗力無 視の場合）および式(2)の当てはめの例
すると，

$$
\begin{aligned}
& \frac{F}{\rho V_{0}^{2} B^{2}}=k_{a}\left\{\exp \left(-k_{b} L\right)-1\right\} \\
& k_{b}=\frac{2 K_{0} \tan \phi}{B}, \quad k_{a}=-\frac{C_{s}}{4 K_{0} \tan \phi}
\end{aligned}
$$

ここで式(2)を図-2(a)の実験データに当てはめ, 最 小二乗法により $C s, K_{0} \tan \varphi$ を推定した。図-2(b)に はこうして補正し，無次元化した荷重を示すととも に，式(2)を当てはめた例も示した。この図より， 式(2)はそれらの実測值の被覆距離による推移をよ く表している. 図-3 には，その方法で推定された 抗力係数 $C s$ と $20 \mathrm{~mm}$ 水の混入率 $\xi$ との関係を示

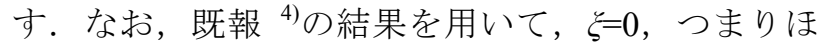
ぼ平坦水群の場合の Cs も推定し, 図示している. が増大するにつれ, 抗力係数 Cs も増大するが, そ の増加率は減少し，いずれある混入率で最大をとる ような感がある. 次項以降ではもう少し, 混入率と Cs との関係について定量的・一般的に考えてみる.

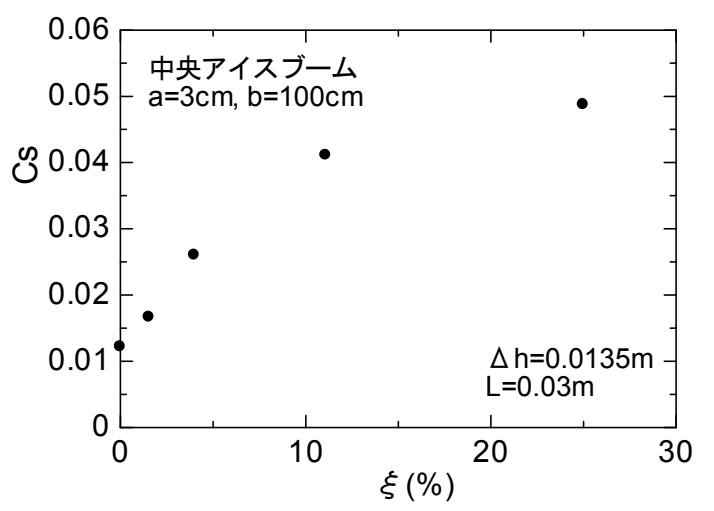

図-3 20mm 水の混入率 $と$ 図-2(b)および式(2)から 推定された推定されたCs との関係

（3）混入率と波数・スペクトル・平均パワー（分 散）との関係

混入率 $\xi$, 凹凸特性を表す平均值，平均パワー (分散）あるいはスペクトルに対応させておくと, 実用的には便利で，汎用性が広がる。まず図-4に 示すように，配合した水群を直線的にみた場合，そ の凹凸形状を矩形波と仮定する。

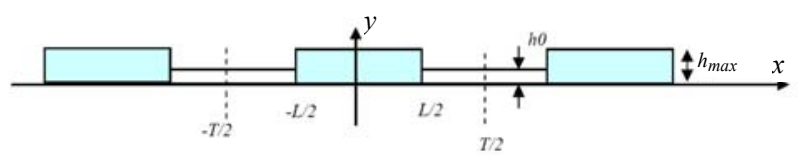

図-4 配合した水群の矩形波としての単純モデル化

いま凸部の幅 $L$ を $20 \mathrm{~mm}$ 水の直径 $(L=0.03 \mathrm{~m})$ とし

(円形の場合には，直径は $L$ の最大值となるが, ここではそのように仮定する），平均的な周期を $T$ とすると，混入率 $\xi$ は $L / T$ となる。 また平均的な 波数 $k p$ は $\xi / L$ と表される. 以上まとめると， 


$$
\xi=\frac{L}{T}, \quad k_{p}=\frac{\xi}{L}
$$

図-5には種々の混入率に対する（線）スペクトル を示した。 なお, その定義により, 縦軸は振幅 $\Delta h$ で除して無次元化するとともに，横軸の波数 $k$ は $L$ を乗じて無次元化している．ただし，本実験の場合， $\xi=1$ が最大值であるから, 最大波数は $33.3 \mathrm{cycle} / \mathrm{m}$ $(k L=1)$ となる.

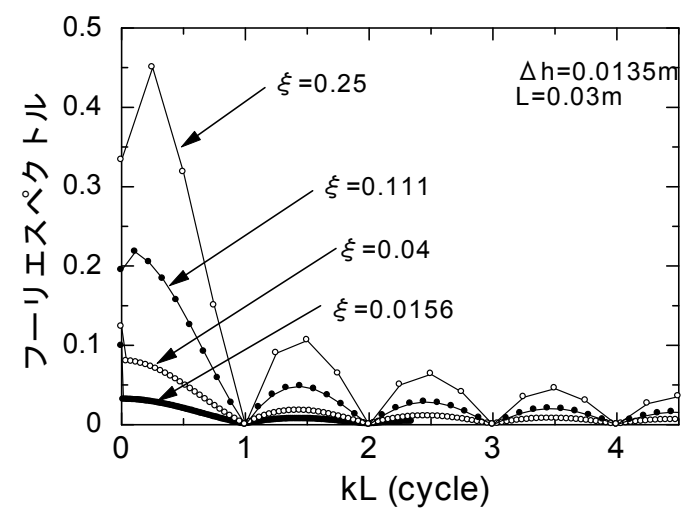

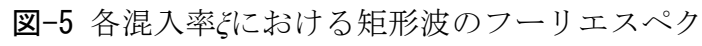
トルの例

また, 水の喫水厚 $h$ の平均值を混入率 $\xi\left(=k_{p} L\right)$ を用いて，表現すると，

$$
\begin{aligned}
\bar{h}=\frac{1}{T} \int_{-T}^{T} h d x & =\frac{L h_{\max }+h_{0}(T-L)}{T} \\
& =\Delta h \xi+h_{0}
\end{aligned}
$$

さらに，凹部を基準としたとき，つまり凸部の平均 值を無次元量で表すと，上式より，

$$
\frac{h-h_{0}}{\Delta h}=\xi
$$

となり, 混入率 $\xi$ となる.

ここに， $h_{\max }$ および $h_{0}$ はそれぞれ $20 \mathrm{~mm}$ 水および $5 \mathrm{~mm}$ 水の喫水厚で，それぞれ $0.018 \mathrm{~m}, 0.0045 \mathrm{~m}$, $\Delta h=h_{\max }-h_{0}$ （凹凸振幅）である.

次に, 水の喫水厚 $h$ の分散 (平均パワー) $C_{0}$ を 混入率 $\xi\left(=k_{p} L\right)$ を用いて，表現すると，

$$
\begin{aligned}
C_{0}= & \operatorname{Var}(h)=\frac{1}{T} \int_{-T}^{T}(h-\bar{h})^{2} d x \\
= & \frac{1}{T}\left\{L\left(h_{\max }-\bar{x}\right)^{2}+(T-L)\left(h_{0}-\bar{x}\right)^{2}\right\} \\
& =\xi(1-\xi) \Delta h^{2}
\end{aligned}
$$

これを，無次元で表すと，

$$
\frac{C_{0}}{\Delta h^{2}}=\xi(1-\xi)
$$

図-6に，式(4b)および式(5b)を図示した。ある $\xi$ (あるいは $k p$ ) で平均パワー（分散值）は最大を 示すが， $\xi=0$ および 1 の極限で， $5 \mathrm{~mm}$ 水および $20 \mathrm{~mm}$ 水の平坦水に近づくから, 分散も減少し, ど こかで最大をもつことになるが，この場合 $\xi=0.5$ で 最大值をとる. つまり, 平面的に薄い氷と厚い氷が 交互に現れるときに分散は最大となる.

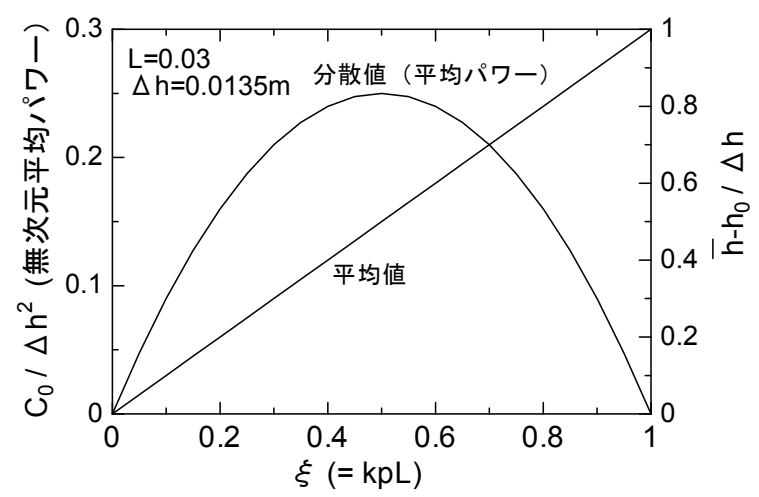

図-6 水群凹凸の波数 $k p$, 混入率 $\xi$ と平均值や平均 パワー（分散）との関係

\section{(4) 他の実験結果 ${ }^{3)}$ との比較}

上田ら ${ }^{3)}$ は，図-7 に示寸ように，一枚の板状のパ ラフィン盤(長さ $0.6 \mathrm{~m}$, 幅 $0.4 \mathrm{~m}$ ) の下面に規則的な凹 凸を設け，これを一定速度でけん引することにより， 凹凸水盤の抗力係数などの推定を試みている. ここ では，本実験で得られた結果と比較してみる。

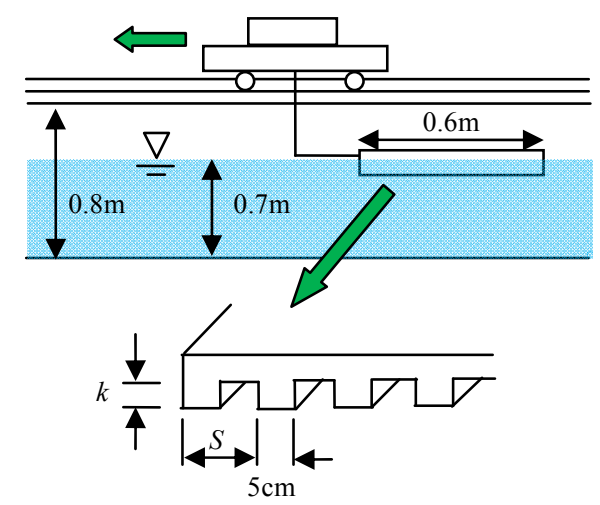

図-7 上田等 ${ }^{3)}$ による凹凸水盤の抗力に関する実験方法

この実験では，凸部の高さ $k$ を $2,4 \mathrm{~cm} の 2$ 通り， 凸部の間隔 $S$ を 4 通り変えて, 実験結果を $S / k$ で整 理している. それによれば, $k=2 \mathrm{~cm}, 4 \mathrm{~cm}$ ともに, $S / k=7.5$ で受ける力は最大となり, その時の摩擦抗 力係数 Cs は 0.0257 となることを示している.また 上田らは，開水路の栈形粗度による抵抗を調べた結 果 ${ }^{9)}$ を用し,$S / k=8$ で最大をとることを示してい る. さらに, この研究は数 $\mathrm{mm}$ 程度の凹凸である にもかかわらず結果はほぼ一致することを強調して いる. 図-8 には，本実験結果の $C s$ を $S / k$ で整理し たものを示した。なお，本研究で用いた記号でいえ ば， $S / k \rightarrow T / \Delta h$ となる。また，同図には上田等の実 
験結果も図示したが，文献では， $S / k$ の推移は抗力 で示されており， $S / k=7.5$ で最大となる $C s$ が示され ているのみであったため, 図中では, 波線でその増 減をイメージするにとどめた。ささら，同図には， $T / \Delta h \rightarrow \infty$, つまり平坦水の場合の抗力係数も波線で 示した. 本実験では $T / \Delta h<8.8$ 以下では実験をして いないが，前述のように， $20 \mathrm{~mm}$ 氷の混入率が大き くなると, $20 \mathrm{~mm}$ 水で構成する平坦な水に近づくた め, 分散が減少し, Cs も低下してくるものと思わ れる. したがって，上田等と同様な傾向を示すと考 えられる。しかし，上田等の結果と比較して，その 抗力係数は約 2 倍ほど本研究の結果の方が大きい. この違いは，(1)流れの状態，つまり上田等の実験で は水を移動させている一方, 本研究では水流を発生 させていることの違いや，水深の違い，水被覆長の 違い等にともなう境界層厚（発達）の違い ${ }^{10}$ ), (2)上 田等の凹凸は規則的で 1 次元的であるが, 本実験で は平面的であり，より不規則性が内在している, 事 などが考えられる。、ずれにしても，本研究と上田 等の実験から推察されることは, 凹凸水の場合の $C s$ は $10^{-2}$ のオーダーであること, T/Ah が 1 のオー ダーで Cs が最大となると予想されること, などが 挙げられる.

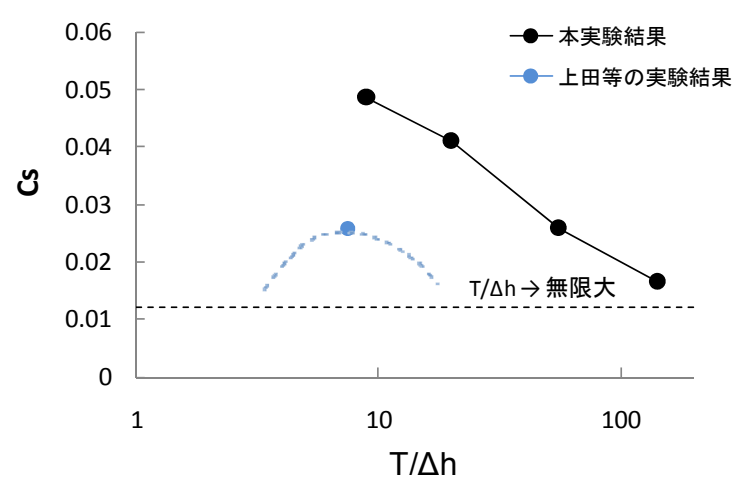

図-8 凸部の間隔と凹凸振幅との比 $(T / \Delta h)$ と抗力係 数との関係および上田等の実験結果との比較

\section{4. 北海道オホーツク海沿岸における流氷群 の摩擦抗力係数の概略推定}

著者等は, 数年にわたり北海道オホーツク海沿岸 部（紋別沖の海象計付近, 沖合 $8.2 \mathrm{~km}$, 水深 $52 \mathrm{~m}$ ) において, ADCP (Acoustic Doppler Current Profiler) と IPS (Ice Profiling Sonar)を海底に設置し, 流水の移動速度, 喫水深などの定点観測を実施して いる例光ば 8). IPS で得られた喫水深の時系列データ を, $\mathrm{ADCP} に よ る$ 流水の移動速度データを用いて, 空間データに変換し，これを流水下面形状と見なし， それらの凹凸特性に関する定量分析を実施している。 図-9に示すように, その底面形状は平坦ではなく, 数 $\mathrm{m}$ の凹凸を有する変形水であることを示してい る ${ }^{8)}$. 変形水は, 静的に凍結した平坦な水の相互の 乗り上げ（rafting）や，圧縮・せん断作用，座屈な どの相互作用によって生じた破壊水片が上下方向に
堆積して形成した氷の総称である。一般に静的に 凍った喫水（水厚）は 1 年に, オホーツク海北部で はせいぜい $1 \sim 1.5 \mathrm{~m}$, 北海道オホーツク海沿岸部で はせいぜい $0.5 \sim 1 \mathrm{~m}$ と考えられるで, これらを越 えるものは，変形水と考えられる．Fukamachi ら ${ }^{11)}$ が, 著者等と同じ観測法で, 湧別沖 $11 \mathrm{~km}$ (水深約 $60 \mathrm{~m})$ において流水観測を実施した結果, 最大 $17 \mathrm{~m}$ の喫水をもつ海水を観測しているほか，著者等の観 測でも $10 \mathrm{~m}$ を超えるものが確認されており, 一般 に大規模化する.

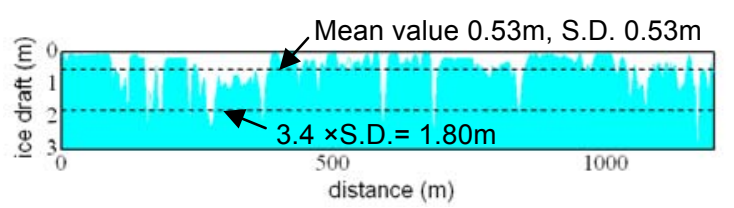

(a) Feb., 2001 (P1)

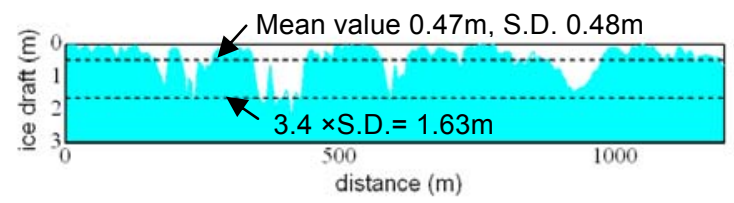

(b) Feb., 2007 (P3)

図-9 流水の下面形状の例 [Kioka et al.,2008] ${ }^{8)}$

一般的に, 流氷群の下面凹凸は非定常性かつ非線形 性を有するきわめて複雑なものであるが, Kioka et $\mathrm{al}^{8}{ }^{8}$ は不規則な下面凹凸の標準偏差を用いて, 直感 的・視覚的な流水下面の凹凸の大きさの指標を提案 することを目的として, 海の波にならって有義振幅 について検討した．有義波高は，それが直感的かつ 自然に感じられる波の高さを与えるといわれている. 標準偏差と, ゼロアップクロス法による有義振幅と の関係は直線であり, 標準偏差に 3.4 を乗じると有 義振幅（海の波の場合は理論的に 4）となることを 示した。実際，図-9に例示したように，局所的に 定常と夕なされる区間 ${ }^{8)}$ の水下面形状において, そ の凹凸の標準偏差に 3.4 を乗じた有義振幅は, その 区間の流水下面の凹凸の高さを直感的・視覚的に表 現し得るものであった。

以上の結果から, オホーツク海における流水群の 摩擦抗力係数の概略推定を試みる. まず, 本実験で 得られた抗力係数を $C_{0} / \Delta h^{2}$ の関数として整理した ものを図-10 に示す．上記の凹凸の有義振幅を本実 験における $\Delta h$ に相当するとし, 標準偏差は $C_{0}$ の平 方根であるから，上記の結果を考慮すると，

$$
\begin{aligned}
& \Delta h=3.4 \sqrt{C_{0}} \\
& \therefore \frac{C_{0}}{\Delta h^{2}}=\left(\frac{1}{3.4}\right)^{2}=0.086
\end{aligned}
$$

が得られ，図-10から， Cs=0.03〜0.04の值が得られ る. これは, 他の観測結果 ${ }^{12}$ で, 水下の流速プロ ファイルを計測することによって推定されたラフな 水の場合の抗力とだいたい同程度である. 


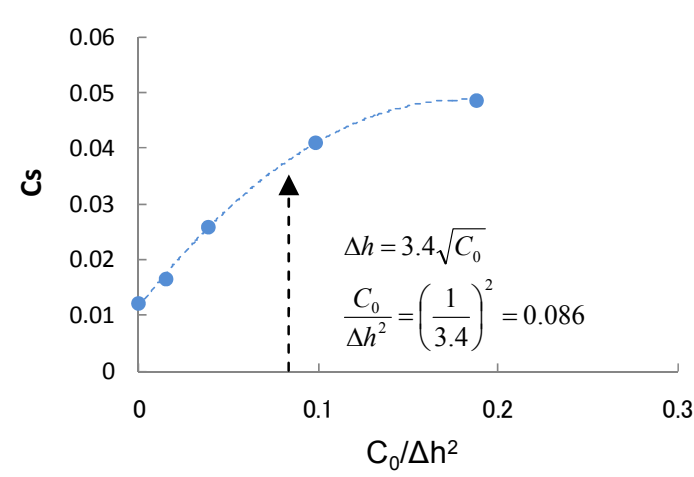

図-10 摩擦抗力係数 $C s$ と $C_{0} / \Delta h^{2}$ との関係

以上のように, 本研究では特に摩擦抗力係数につ いて考察した. 本研究の議論から, 凸部の高さなど 凹凸のスケールにこだわらず，凹凸形状が相似，つ まり，T/Ah あるいは $C_{0} / \Delta h^{2}$ 等が同一であれば，同 一の Cs を与えることになる．前述したように凸部 の高さが影響するのは圧力（形状）抗力と考えられ， 別途考慮する必要がある. なお, 圧力（形状）抗力 係数は $10^{-1}$ のオーダーが報告されている ${ }^{3)}$. ただし， 水群の被覆距離が長くなれば, 相対的にその影響は 小さくなると考えられる.

\section{5.まとめ}

本研究では, 特に凹凸の摩擦抗力成分に着目した 様々な凹凸状態の水群の伝達荷重や抗力係数などに ついて調べた. 主要な結論を以下に示す.

【 平坦な水群の場合と同様, アイスブームへの 伝達荷重は流速の二乗に比例した。伝達荷重 と水群被覆長の関係は, 平坦な水群の場合に はほぼ直線であったが，凹凸の場合には，曲 線的（増加率が減少）であった。また, 流下 方向の伝達荷重の理論モデルは, この実験値 の傾向を良く表すことを確認し（図-1），この モデルより, 各凹凸状態の氷群の抗力係数を 推定した。

- 高さ（振幅）一定で異なる $(20 \mathrm{~mm}$ 厚水盤の)混 入率 $\xi$ に対応する各凹凸状態を表す波数や分 散などの単純な指標を算定し, それらと抗力 係数との関係を推定した.

-上田等の実験も考慮して, 抗力係数は, $10^{-2}$ の オーダーであること, 凹凸の周期と振幅の比

(T/Ah) が 1 のオーダーで Cs が最大となるこ とが推察された。

- 本実験結果から, オホーツク海における流水 群の摩擦抗力係数の概略推定を試みた. 現地 観測結果の有義振幅と標準偏差との関係から, およそ $0.03 \sim 0.04$ と推定された.

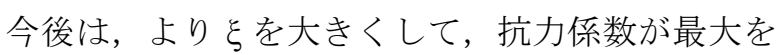

もつ事を確認するとともに，凸部の形状を，矩形の みならず，円形，三角形など様々な形状も試み，凸 部の高さも不規則に変化させた実験等も実施する必 要がある.あわせて, 円柱形の氷盤のみならず, 種々の形状の水盤で実施する必要がある.

\section{参考文献}

1）榎国夫, 國松靖, 大平正治, 村木義男, 佐伯浩 : 新 型 Ice Boom の開発, 第 7 回寒地技術シンポジウム論 文集, pp.638-643,1991.

2）榎国夫, 石井千万太郎, 國松靖, 佐伯浩: Ice Boom による氷盤移動制御, 海洋開発論文集, Vol.8, pp.153-158, 1992

3）上田俊也, 佐伯浩, 山下俊彦, 村木義男, 榎国夫 : 浮水盤に作用する流体力に関寸る実験的研究, 海洋 開発論文集, Vol.8, pp.135-140, 1992.

4) 木岡信治, 蒔田俊輔, 山本泰司, 森昌也, 竹内貴 弘：流水群と防水施設の相互作用に関寸る水理模型 実験，海洋開発論文集, Vol.24, pp.1035-1040, 2008.

5）木岡信治, 森昌也, 山本泰司, 遠藤強, 竹内貴弘： 流水群とアイスブームの相互作用に関する水理模型 実験とその数値計算に関する基礎的研究, 海洋開発 論文集, Vol.25, pp.1053-1058, 2009.

6) 木岡信治, 竹内貴弘, 蒔田俊輔: 水群下面に作用寸 る抗力に関する理論的一考察, 寒地技術論文 - 報告 集, Vol.23, pp.213-218, 2007.

7）木岡信治, 河合孝治, 竹内貴弘, 牧田佳巳 : サロマ 第二湖口における流水挙動と水路護岸に作用寸る 流水接触荷重の数值計算, 土木学会論文集 B2(海岸 工学), Vol.66, No1, pp. 786-790, 2010.

8) Kioka, S, Yamamoto, Y, Sutou, A and T. Takeuchi : Characteristics of Ice Bottom Topography from the Sea of Okhotsk off Hokkaido - Observation Results in 2007 -, Proc. of the 18th International Offshore and Polar Engineering Conference, Vol.1, pp. 594-601, 2008.

9）足立昭平：人工粗度の実験的研究，土木学会論文集， 第 104 号, pp. 33-44, 1964.

10) 木岡信治, 竹内貴弘, 蒔田俊輔 : 水群下面に作用寸 る抗力に関する理論的一考察, 寒地技術論文 - 報告 集, Vol.23, pp.213-218, 2007.

11) Fukamachi, Y., Mizuta, G., Ohshima, K.I., Toyota,T., Kimura, N.and M.Wakatsuchi, : Sea ice thickness in the southwest Sea of Okhotsk revealed by a moored iceprofiling sonar," J. Geophys, Res., Vol.111, C09018, doi:10.1029/2005JC003327, 2006.

12) Johannessen, O.M. : Note on Some Vertical Profiles Below Ice Floes in the Gulf of St.Lawrence and near the North Pole, J.Geophys.Res., Vol.75, No.15, pp.28572861, 1970. 